\title{
PENGELOLAAN WAKAF TANAH PRODUKTIF DI KOTA BANDA ACEH
}

\author{
M. Thaib \\ Program Studi Doktor Ilmu Hukum \\ Pascasarjana Universitas Islam Bandung \\ e-mail: mthaib.zakaria@gmail.com
}

\begin{abstract}
Abstrak- Wakaf adalah sumber pemberdayaan ekonomi masyarakat, yang memiliki potensi dan manfaat ekonomi jika dikelola secara efektif dan efisien untuk kepentingan ibadah dan kesejahteraan rakyat. Implementasi Undang-Undang Nomor 41 Tahun 2004 tentang Wakaf untuk peningkatan kesejahteraan masyarakat di Kota Banda Aceh melalui wakaf tanah produktif, belum berkontribusi terhadap peningkatan kesejahteraan masyarakat, karena beberapa faktor. Mereka adalah: Pemahaman Muslim tentang wakaf, jumlah tanah wakaf yang tidak strategis, perbedaan pendapat tentang pengalihan wakaf untuk tujuan produktif, jumlah tanah wakaf yang tidak bersertifikat, dan Nazhir masih tradisional dan konsumtif.
\end{abstract}

\section{Kata kunci: Wakaf, Pemberdayaan Ekonomi, Lahan Produktif.}

Abstract-Waqf is a source of economic empowerment of people, which has potential and economic benefits if it is being managed effectively and efficiently for the benefit of worship and the welfare of the people. The implementation of the Act Number 41 of 2004 on Waqf for the improvement of community welfare in Kota Banda Aceh through productive land waqf, yet has not contributed to the improvement of people's welfare, due to several factors. They are: Muslim understanding of waqf, the number of waqf land which is not strategic, dissenting opinion on the transfer of waqf for productive goals, the number of uncertified waqf land, and Nazhir is still traditional and consumptive.

\section{Keywords: Waqf, Economic empowerment, Productive Land.}

\section{A. PENDAHULUAN}

Sejak awal pertumbuhan Islam, wakaf menjadi salah satu elemen penunjang perkembangan agama, ekonomi, dan sosial masyarakat (Juhaya S. Praja dan Mukhlisin Muzarie, 2009:11; Suparman Usman, 1999:2; Ahmad Azhar, 1993:74). Hampir semua rumah ibadah, lembaga pendidikan Islam dan lembaga keagamaan Islam lainnya di bangun di atas tanah wakaf. Wakaf yang didefinisikan sebagai aset yang disumbangkan untuk kemanusiaan dalam jangka waktu yang relatif lama memiliki fungsi ritual (ubudiyah) dan sosial (Surahwardi K. Lubis, 2012:102).

Pengertian wakaf menurut syari'ah yang diatur dalam hukum fikih, ialah menyerahkan suatu hak milik yang tahan lama zatnya kepada 
seseorang atau Nazhir (penjaga dalam lingkungan masyarakat muslim wakaf), atau kepada suatu badan Indonesia, dan apa yang diwakafkan pengelola, dengan ketentuan bahwa oleh masyarakat muslim, dapat hasil atau manfaatnya digunakan berbagai macam benda, ada yang kepada hal-hal yang sesuai dengan ajaran syari'at Islam. Dalam hal tersebut benda yang diwakafkan bukan lagi hak milik yang mewakafkan, dan bukan pula milik tempat menyerahkan, tetapi menjadi hak Allah (hak ummat) (Abdurrahman, 1994:25).

Adapun tujuan dari wakaf harus untuk kebaikan atas nama Allah dan untuk kepentingan agama Islam (Ismail Muhammad Syah, 1994:249). Pelaksanaan dan segala permasalahan tentang wakaf juga harus sesuai dengan tujuan dari fiqih Islam yakni untuk mewujutkan kesejahteraan di dunia dan kebahagiaan di akhirat bagi umat manusia (Hasbi A.R, 1985:1). Maka prinsip pembaharuan/tajdid hukum adalah mengedepankan kemaslahatan umat yang berdasarkan keadilan dan kemanfaatan serta mencegah timbul kerusakan (M. Hasballah Thaib, 2002:21).

Sampai saat ini pelaksanaan wakaf terus hidup dan berkembang di berupa tanah, ada yang berupa kitab suci Al-Qur'an dan sebagainya (Mohammad Koesno, 1991:117).

Menurut Anwar Haryono, wakaf adalah penglepasan hak milik seseorang muslim yang hanya bermanfaat atau hasilnya (buahnya) dipergunakan untuk kepentingan umum. Penglepasan hak milik secara wakaf ini dinilai sebagai shadaqah jariah (continue) (Suparman Usman, 1999:26). Mewakafkan adalah perbuatan hukum seseorang/badan hukum yang memisahkan sebagian dari harta kekayaannya yang berupa tanah milik dan melembagakannya untuk selama-lamanya untuk kepentingan peribadatan/keperluan umum lainnya sesuai dengan ajaran Islam (Andi Tahir Hamid, 2005:100).

Negara Indonesia merupakan suatu negara yang mayoritas penduduknya beragama Islam. Sebagaimana kita ketahui, bahwa agama Islam menganjurkan untuk melaksanakan ibadah, yang salah 
satunya yaitu dengan melaksanakan wakaf. Pada dasarnya wakaf tidak hanya mencakup tanah sebagai benda tidak bergerak, akan tetapi juga mencakup benda bergerak misalnya uang atau mobil, surat berharga dan sebagainya. Wakaf benda tidak bergerak yaitu tanah, yang pada umumnya seringkali dilakukan dalam masyarakat (R. Van Dijk, Tt:54).

Berbagai jenis hak dapat melekat pada tanah, dengan perbedaan prosedur, syarat dan ketentuan untuk memperoleh hak tersebut. Di dalam Hukum Adat dikenal hak membuka tanah, hak wenang pilih, hak menarik hasil, sampai hak milik (R. Van Dijk, Tt:54). Pada beberapa kelompok masyarakat tertentu, hubungan dengan tanah demikian eratnya, sehingga dianggap mempunyai nilai magis. Pembukaan tanah dengan menebang hutan dianggap dapat mengganggu keseimbangan magis lingkungan itu. Karena itu perlu adanya upacara tertentu untuk memulihkan keseimbangan magis tersebut (Adijani al Alabij, 1989:1).

Masalah tanah ini diatur dalam Hukum Agraria Nasional, yang tertuang dalam Undang-Undang Nomor 5 Tahun 1960 tentang Peraturan Dasar Pokok-Pokok Agraria dan ditindak lanjuti oleh berbagai peraturan perundanganundangan lainnya. Dalam salah satu konsiderannya disebutkan bahwa berhubung dengan apa yang disebut dalam pertimbangan-pertimbangan di atas perlu adanya Hukum Agraria Nasional, yang berdasar atas hukum adat tentang tanah yang sederhana dan menjamin kepastian hukum bagi seluruh rakyat Indonesia, dengan tidak mengabaikan unsur-unsur yang bersandar pada hukum agama. Salah satu halyang bersandar pada hukum agama yang menyangkut tanah ini adalah perwakafan tanah (Taufik Hamami, 2003:3).

Pengaturan hubungan hukum antara orang dengan tanah perlu dilandasi dengan suatu alat bukti otentik sebagai dasar perolehan tanah sebagaimana Peraturan Pemerintah Nomor 24 Tahun 1997 tentang Pendaftaran Tanah yaitu melalui suatu perbuatan hukum yang mengakibatkan beralihnya hak atas tanah antara lain karena jual beli, hibah, wakaf, tukar menukar, 
penyertaan modal, dan lelang. Untuk mewujutkan kepastian hukum terhadap suatu subyek dan obyek hak atas tanah, diperlukan suatu alat pembuktian yang menerangkan secara fisik, yuridis dan hubungan hukum konkrit yang berlaku antara si empunya dengan tanah yang dikuasainya. Bukti kepemilikan dan penguasaan bidang tanah secara formal telah diatur secara khusus dalam Peraturan Pemerintah Nomor 24 Tahun 1997 tentang Pendaftaran Tanah dan lebih lanjut diatur dalam Peraturan Menteri Negara Agraria/Kepala Badan Pertanahan Nasional Nomor 3 Tahun 1997 Pasal 76 ayat (1) dan (2), dan Peraturan Pemerintah Nomor 28 Tahun 1977 tentang Wakaf.

Pada masa pertumbuhan ekonomi yang cukup memprihatinkan ini sesungguhnya peranan wakaf di samping instrumen lainnya, dapat dirasakan manfaatnya untuk meningkatkan taraf hidup masyarakat, khususnya di bidang ekonomi, apabila wakaf dikelola secara baik (Departemen Agama Republik Indonesia, 2003:2).
Bahwa di Indonesia sampai saat ini potensi wakaf sebagai sarana bagi kepentingan masyarakat belum dikelola dan didayagunakan secara maksimal dalam ruang lingkup nasional. Dari praktik pengalaman wakaf, dewasa ini tercipta suatu persepsi tertentu mengenai wakaf. Pertama, wakaf itu umumnya berwujud benda tidak bergerak khususnya tanah. Kedua, dalam kenyataan di atas tanah itu didirikan masjid atau madrasah. Ketiga, penggunaannya didasarkan pada wasiat pemberi wakaf (wakif) selain itu timbul penafsiran bahwa untuk menjaga kekekalannya, tanah wakaf tidak boleh diperjualbelikan. Padahal jika tanah wakaf bisa diagunkan, maka suatu organisasi semacam Nahdatul Ulama dan Muhammadiyah atau Universitas bisa mendapatkan dana pinjaman yang diputarkan sehingga menghasilkan sesuatu. Demikian pula penggunaan tanah wakaf dari Wakif yang berbeda tidak bisa digabungkan, karena seolah-olah aset wakaf telah kehilangan identitas individual Wakifnya. Padahal kalau beberapa harta wakaf bisa dikelola bersama, maka bisa dihimpun 
berbagai faktor produksi untuk dengan luasnya sejumlah 797.610,61 sesuatu investasi, kalau perlu dengan menjual sesuatu aset wakaf untuk dijadikan modal finansial (Achmad Djunaidi dan Thobieb al Asyhar, 2005:11).

Bahwa pada tahun 2015 jumlah tanah wakaf yang telah terdata dalam wilayah Kota Banda Aceh sebagaimana diperoleh data dari Kantor Kementrian Agama Kota Banda Aceh sejumlah 751 Persil

$\mathrm{M}^{2}$, yang sudah bersertifikat sebanyak 451 Persil (60,05\%), dengan luas sejumlah 508.161,08 $\mathrm{M}^{2}$, dan 300 persil $(39,95)$ belum bersertifikat, serta masih banyak yang belum dilaporkan oleh Nazhir dan pihak Kantor Urusan Agama KecamatanKecamatan ke Kantor Kementerian Agama Kota Banda Aceh dengan perincian sebagai berikut:

Tabel 1.1. Data Tanah Wakaf Dalam Kota Banda Aceh Tahun 2015 Berdasarkan Status dan Luas Areal Per Kecamatan

\begin{tabular}{|c|l|c|c|c|c|}
\hline \multirow{2}{*}{ No } & \multirow{2}{*}{ Kecamatan } & \multicolumn{2}{|c|}{ Jumlah } & \multicolumn{2}{c|}{ Sudah Sertifikat } \\
\cline { 3 - 6 } & & Persil & Luas $\mathbf{M}^{\mathbf{2}}$ & Persil & Luas M $^{\mathbf{2}}$ \\
\hline 1. & Kuta Alam & 78 & 87.507 .70 & 20 & 25.764 .00 \\
\hline 2. & Baiturrahman & 107 & 106.122 .28 & 72 & 47.434 .00 \\
\hline 3. & Meuraxa & 76 & 119.074 & 74 & 118.193 .00 \\
\hline 4. & Syiah Kuala & 90 & 156.006 .00 & 47 & 89.969 .00 \\
\hline 5. & Bandar Raya & 65 & 50.088 .08 & 28 & 35.834 .08 \\
\hline 6. & Jaya Baru & 86 & 67.173 .61 & 21 & 27.347 .00 \\
\hline 7. & Lueng Bata & 68 & 74.707 .94 & 39 & 51.381 .00 \\
\hline 8. & Kuta Raja & 122 & 58.527 .00 & 115 & 52.789 .00 \\
\hline 9. & Ulee Kareng & 59 & 78.404 .00 & 35 & 59.450 .00 \\
\hline & Jumlah & 751 & 797.610 .61 & 451 & 508.161 .08 \\
\hline
\end{tabular}

Sumber: Kantor Kementrian Agama Kota Banda Aceh.

yang sudah diberdayakan untuk tempat ibadah, tempat pendidikan, asrama anak yatim, dan dalam bentuk toko dan lain-lain. dan masih juga

Pada umumnya peruntukan tanah wakaf di Kota Banda Aceh adalah digunakan sebagai Kuburan, Masjid, Meunasah, Balai Pengajian, Rumah Fakir Miskin. Sementara ini terdapat dalam bentuk tanah kosong, padahal tanah kosong ini dikembangkan sedemikian rupa maka sangat besar manfaatnya bagi 
pengembangan untuk pelaksanaan pemberdayaan tanah wakaf untuk kemaslahatan masyarakat (Achmad Djunaidi dan Thobieb al Asyhar, 2005:77).

Pemberdayaan

dan pengembangan wakaf produktif merupakan hal yang baru dalam perkembangan wakaf di Indonesia. Agar hal ini dapat terlaksana dengan baik, maka diperlukan organisasi pengelola wakaf yang mampu menjalin kemitraan dengan lembaga lainnya yang peduli terhadap dunia wakaf. Selama ini terlihat, pemberdayaan dan pengembangan wakaf mengalami banyak hambatan dan rintangan, terutama dalam hal pengelolaan wakaf yang telah produktif, sehingga kurang dirasakan manfaatnya kepada masyarakat yang memerlukannya. Oleh karena itu pembercayaan dan pengembangan wakaf harus diarahkan kepada wakaf produktif melalui manajemen yang sesuai dengan syariat Islam dengan menggerakkan seluruh potensi yang terkait.

Pemberdayaan dan pengembangan harta benda wakaf, dilakukan secara produktif antara lain dengan investasi, penanaman modal, produksi, kemitraan, perdagangan, agrobisnis, pertambangan, perindustrian, pengembangan teknologi, pembangunan gedung, apartemen, rumah susun, pasar swalayan, pertokoan, sarana pendidikan, ataupun usaha yang tidak bertentangan dengan syariah. Menyangkut dengan pengelolaannya agar tujuan wakaf bisa tercapai, ketentuannya terdapat pada Pasal 42 Undang-undang Nomor 42 Tahun 2004 bahwa, Nazhir wajib mengelola dan mengembangkan harta benda wakaf sesuai dengan tujuan, fungsi dan peruntukannya. Kemudian pada Pasal 43 juga dikemukakan, pengelolaan dan pengembangan harta benda wakaf oleh Nazhir sebagaimana dimaksud Pasal 42 dilaksanakan sesuai dengan prinsip syariah.

\section{B. HASIL DAN PEMBAHASAN}

Pada tanggal 27 Oktober 2004, Pemerintah dengan persetujuan DPR mensahkan Undang-Undang Nomor 41 Tahun 2004, tentang Wakaf, yang salah satu konsiderannya menyebutkan : Bahwa Lembaga 
Wakaf sebagai Pranata Keagamaan memiliki potensi dan manfaat ekonomi perlu dikelola secara efektif dan efesien untuk kepentingan ibadah dan memajukan kesejahteraan umum. Kemudian untuk melengkapi aturan yang ada tentang wakaf, diterbitkan Peraturan Pemerintah Nomor 42 Tahun 2006 sebagai aturan Pelaksana Undang-Undang Nomor 41 Tahun 2004 tentang Wakaf. Peraturan tersebut dikeluarkan dalam rangka memberikan payung hukum masalah perwakafan dan pengelolaannya.

Salah satu pertimbangan dikeluarkannya Undang-Undang Nomor 41 Tahun 2004 tentang Wakaf, dan Peraturan Pemerintah Nomor 42 Tahun 2006 tentang Pelaksanaannya, adalah perlunya ditingkatkan peran wakaf sebagai pranata keagamaan yang tidak hanya bertujuan menyediakan berbagai sarana ibadah, dan sosial, tetapi juga memiliki kekuatan ekonomi yang berpotensi antara lain untuk memajukan kesejahteraan umum, sehingga perlu dikembangkan pemanfaatannya sesuai dengan prinsip syariah. Supaya hal ini dapat berjalan dengan baik sebagaimana yang diharapkan, maka perlu menggali dan mengembangkan potensi yang terdapat dalam pranata keagamaan yang memiliki manfaat ekonomi.

Terkait dengan pemberdayaan wakaf untuk kesejahteraan masyarakat, Pasal 43 ayat 2 UndangUndang Nomor:42 Tahun 2004 menyebutkan: Pengelolaan dan pengembangan benda wakaf dilakukan secara produktif antara lain dengan cara pengumpulan, investasi, penanaman modal, produksi, kemitraan, perdagangan, agrobisnis, pertambangan, perindustrian, pengembangan teknologi, pembangunan gedung, apartemen, rumah susun, pasar swalayan, pertokoan, perkantoran, sarana pendidikan ataupun sarana kesehatan dan usaha yang tidak bertentangan dengan syariah.

Upaya dan perhatian pemerintah terhadap lembaga perwakafan tersebut menunjukkan betapa pentingnya lembaga wakaf dalam rangka meningkatkan kesejahteraan sosial dan ekonomi umat. Dalam praktek di masyarakat prosentase peruntukan tanah wakaf 
lebih banyak ditujukan untuk hal-hal yang bersifat keibadatan misalnya untuk masjid, mushalla, panti asuhan, pondok pesantren yang tidak mempunyai nilai produktif.

Dari sisi ekonomi sebenarnya lembaga wakaf dapat saja diberuntukkan bagi hal yang mengandung suatu kebaikan dan kemaslahatan masyarakat yang bersifat produktif selama tidak menyalahi ajaran agama Islam. Hal tersebut sebagaimana dilakukan oleh beberapa negara Islam Timur Tengah yang mempunyai pengalaman di bidang perwakafan, contohnya pemerintahan Mesir dipimpin oleh Presiden Jamal Abdul Naser memerlukan pinjaman uang, pemerintah meminjam ke badan wakaf Al Azhar (pinjaman tanpa bunga) tidak ke lembaga moneter internasional dan tidak negeri lain (Rachmat Djatniko, 1992:10).

Wakaf termasuk di dalamnya wakaf tanah mempunyai kontribusi solutif terhadap persoalan ekonomi kemasyarakatan dalam arti wakaf tanah mengandung potensi sumber daya ekonomi umat. Wakaf dalam tataran idiologis berbicara tentang bagaimana nilai-nilai yang seharusnya diwujudkan oleh dan untuk umat Islam, sedangkan pada wilayah paradigma sosial - ekonomis, wakaf menjadi jawaban konkrit menghadapi realitas problematika kehidupan masyarakat.

Salah satu konsep sumber daya ekonomi apabila dikaitkan dengan tanah mungkin dapat dipahami, bahwa tanah merupakan natural resources (sumber daya alam), sedangkan manusia sebagai human resources (sumber daya manusia). Dalam pengalaman sejarah, ekonomi suatu bangsa dan negara akan dapat tumbuh dan berkembang apabila kedua faktor tersebut dapat dikelola sebaik mungkin dengan menggunakan penemuan baru dalam ilmu pengetahuan dan teknologi).

Bertolak dari pemikiran di atas, maka tanah wakaf sebagai suatu lembaga sosial Islam, pada hakekatnya mempunyai fungsi yang sama dapat digunakan sebagai salah satu sumber daya ekonomi (M. Thaher Azhary, 1992:13).

\section{Perwakafan Tanah Milik di} Kota Banda Aceh 
Undang-Undang Nomor 41 Tahun 2004 tentang Wakaf telah diberlakukan di Indonesia. Harta tanah wakaf mempunyai potensi yang amat besar dan amat penting guna pemenuhan terhadap berbagai kebutuhan kepentingan masyarakat, seperti untuk kepentingan keagamaan, kepentingan sosial dan ekonomi, oleh karenanya masalah perwakafan tanah milik perlu diatur dan dikelola dengan secermat mungkin.

Secara historis, anjuran dan misi wakaf untuk menciptakan kesejahteraan sosial sebenarnya telah dicontohkan di zaman Kejayaan Islam di masa lalu, dimasa dinasti Abbasiyah, Wakaf telah berkembang sedemikian rupa sehingga menjadi sumber pendapatan negara. Ketika itu wakaf yang pada awalnya meliputi berbagai aset semacam masjid, mushalla, sekolah, tanah pertanian, rumah, toko, kebun/pabrik roti, bangunan kantor, gudang pertanian, tempat perniagaan, pasar, tempat pemandian, gudang beras, dan lainlain, pada akhirnya bisa diambil manfaatnya sebagai Instrumen pendapatan negara.
Jika meneliti lebih jauh, maka akan didapatkan bahwa di negaranegara tersebut tidak hanya berupa tanah atau bangunan, tetapi juga berupa investasi saham, uang, real estatate, tanah pertanian, flat yang kesemuanya dikelola dengan baik dan produktif, sehingga hasilnya dapat digunakan untuk mewujudkan kesejahteraan umat.

Melihat perkembangan dan pengelolaan harta wakaf yang telah dilakukan oleh berbagai negara Islam yang telah melaksanakan wakaf dan telah berhasil memberdayakan harta wakaf sehingga dapat menopang kehidupan perekonomian negara, maka dapat kita ketahui pada dasarnya harta wakaf dapat dikelola dan dikembangkan menuju upaya peningkatan hasil yang bersifat ekonomi, sehingga manfaat harta wakaf itu dapat dinikmati oleh masyarakat luas demi kesejahteraan dan kemaslahatan umat. Pengelolaan harta wakaf tetap dipertahankan sedangkan pengembangan manfaat harta wakaf tetap diusahakan. Di sinilah nilai filosofisnya harta wakaf sebagai sumber/potensi ekonomi umat. 
Bagi masyarakat di Kota Banda Aceh perwakafan tanah milik telah dikenal dan dilaksanakan oleh umat Islam sejak agama Islam masuk ke Aceh. Perwakafan tanah milik merupakan salah satu bentuk obyek wakaf. Wakaf sebagai suatu lembaga Islam telah menjadi salah satu penunjang bagi perkembangan kehidupan agama dan sosial masyarakat Islam di Kota Banda Aceh. Jika memperhatikan kenyataan yang ada di wilayah Kota Banda Aceh yang terdiri dari 9 Kecamatan, menunjukkan kecenderungan umat Islam di kawasan ini dalam menunaikan wakaf tanah milik dapat dikatakan baik. Dari data yang ada pada Kementrian Agama Kota Banda Aceh, menunjukkan wakaf tanah milik tersebar di seluruh Kecamatan. Setidaknya ada 751 persil wakaf tanah milik dengan luas 797.610.61 $\mathrm{m}^{2}$.

Pemanfaatan wakaf tanah milik pada umumnya tanah kosong, dan ada beberapa bagian yang sudah ada bangunan, adapun peruntukkan tanah wakaf di Kota Banda Aceh peruntukannya adalah sebagai berikut: a. Mesjid;

b. Meunasah;

c. Musalla;

d. Langgar;

e. Taman Pendidikan Al-qur'an;

f. Balai Pengajian;

g. Sekolah Dasar;

h. Madrasah Ibtidaiyah;

i. Pasantren;

j. Kuburan Umum;

k. Rumah Fakir/Miskin;

1. Puskesmas;

m. Polindes;

n. Rumah Toko;

o. Rumah Sewa;

p. Rumah Kos;

q. Kios;

r. Pasar;

s. Rumah Batu;

t. Perumahan;

u. Gudang;

v. Lapangan olah raga;

w. Tanah Pertanian;

x. Bengkel;

y. Kantor Desa.

Khusus mengenai wakaf tanah produktif di Kota Banda Aceh ada 40 persil $(5,32 \%)$, adapun tanah wakaf produktif peruntukannya adalah sebagai berikut:

a. Rumah Toko;

b. Rumah Sewa;

c. Rumah Kos;

d. Kios;

e. Pasar;

f. Rumah Batu;

g. Perumahan;

h. Gudang;

i. Tanah Pertanian;

j. Bengkel. 
Dorongan sebagian besar umat Islam di kawasan Kota Banda Aceh dalam mewakafkan tanah miliknya, cenderung melihat kepentingan yang ada kaitannya dengan masalah ibadah, utamanya tempat ibadah. bahwa wakaf mempunyai peran yang besar dalam pemberdayaan ekonomi umat, meskipun menilai sebagian besar tanah wakaf di Kota Banda Aceh belum dikelola secara produktif, karena masih banyak wakaf tanah yang berupa tanah kosong dan belum dimanfaatkan.

Kalangan masyarakat Islam di Kota Banda Aceh memiliki kebiasaan untuk berwakaf tanah milik itu sudah cukup lama, sejalan dengan perkembangan agama Islam di Aceh. Namun dalam pemberdayaan terhadap tanah wakaf itu pengeloaannya belum dilakukan pelaksanaan secara optimal, sehingga hasil dari pengelolaannya itu belum sepenuhnya dapat diwujudkan guna menunjang untuk memenuhi berbagai kebutuhanpeningkatan kesejahteraan masyarakat yang secara menyeluruh. Keberadaan tanah wakaf memerlukan adanya suatu perhatian yang serius di dalam pengelolaannya dan perlu segera dilakukan penanganan yang secara professional agar hasilnya dapat lebih optimal.

Untuk mengukur kontribusi pelaksanaan wakaf tanah milik di Kota Banda Aceh adalah dengan melihat pemanfaatan dan penggunaan tanah wakaf tersebut. Pada umumnya tanah-tanah wakaf tersebut, pengelolaannya masih bersifat komsumtif dan tradisional. Dengan demikian, kontribusi terhadap peningkatan kesejahteraan masyarakat belum dapat dirasakan walaupun sudah diberdayakan, terutama wakaf tanah milik yang berfungsi sosial, misalnya untuk sarana dan prasana pendidikan, dan pondok pesantren. Sedang wakaf tanah milik yang mempunyai kontribusi langsung terhadap ekonomi umat dapat dikatakan masih kurang walaupun jika menilik pemanfaatan tanah milik yang ada pada saat ini sudah ada 40 bidang yang diklasifikasikan sebagai wakaf tanah produktif.

Harta tanah wakaf yang dikelola secara produktifitas masih sangat sedikit, karena masih ada sebagian kecil dari warga muslim 
yang berwawasan sempit, yang masih memiliki suatu pandangan terhadap penggunaan harta tanah wakaf itu hanya diutamakan guna pemenuhan kebutuhan sarana tempat peribadatan saja. Peluang pemanfaatan harta tanah wakaf tersebut di samping dapat dipergunakan sebagai tempat ibadah, dan dapat dipergunakan untuk kepentingan sosial (seperti untuk sarana tempat pendidikan, untuk rumah sakit, untuk asrama dan sebagainya), harta tanah wakaf dapat dikelola secara produktifitas ekonomi.

Dengan cara peningkatan pengelolaan potensi dan manfaat ekonomi tanah wakaf, maka wakaf berpotensi untuk memajukan kesejahteraan umum. Di dalam upaya meningkatkan potensi dan manfaat ekonomi harta benda wakaf, maka pengelolaan harta benda wakaf harus ditingkatkan dan dikembangkan pemanfaatannya sesuai dengan tujuan dan fungsi wakaf dengan berlandaskan pada prinsip syari'ah. Konsep ini memungkinkan pengelolaan benda wakaf dapat memasuki wilayah kegiatan produktivitas ekonomi dalam arti luas, sepanjang pengelolaan tersebut sesuai dengan prinsip manajemen dan ekonomi syariah.

Pemanfaatan harta tanah wakaf secara produktifitas ekonomi harus dikelola secara professional, dengan mencari potensi nilai ekonominya. Untuk menunjang usaha tersebut maka diperlukan adanya peningkatan kemampuan professional Nazhir dalam pengelolaan terhadap tanah wakaf.

\section{Pendaftaran Tanah Wakaf di Kota Banda Aceh \\ Dengan diwakafkannya hak} milik atas tanah, maka status hukum hak milik itu menjadi hapus, tetapi tidak menjadi tanah negara, melainkan mempunyai status khusus sebagai tanah wakaf yang diatur menurut Hukum Islam.

Mengingat perwakafan tanah milik secara nyata sarat dengan unsur-unsur yang bersandar pada hukum agama, maka sebagai tindak lanjut dari ketentuan Pasal 49 ayat (3) UUPA, telah dikeluarkan Peraturan Pemerintah Nomor 28 Tahun 1977 tentang Perwakafan Tanah Milik. Dalam konsiderans Peraturan Pemerintah Nomor 28 Tahun 1977 itu disebutkan bahwa: 
a. Bahwa wakaf adalah salah satu lembaga keagamaan yang dapat dipergunakan sebagai salah satu sarana guna pengembangan kehidupan khususnya bagi umat Islam dalam rangka mencapai kesejahteraan spiritual dan menuju masyarakat adil makmur berdasarkan Pancasila.

b. Bahwa peraturan perundangundangan yang ada yang mengatur tentang perwakafan tanah milik selain belum memenuhi kebutuhan akan cara-cara perwakafan juga membuka keinginan timbulnya hal-hal yang tidak diinginkan disebabkan tidak adanya data yang nyata dan lengkap mengenai tanahtanah yang diwakafkan.

Sebagai tindak lanjut dari Peraturan Pemerintah Nomor 28 Tahun 1977 tersebut, Pemerintah telah mengeluarkan beberapa peraturan pelaksanaan, antara lain:

a. Peraturan Menteri Dalam Negeri Nomor 6 Tahun 1977 tentang Tata Pendaftaran Tanah mengenai Perwakafan Tanah Milik.

b. Peraturan Menteri Agama Nomor 1 Tahun 1978 tentang Peraturan Pelaksanaan Peraturan Pemerintah Nomor 28 Tahun 1977 tentang Perwakafan Tanah Milik.

c. Instruksi Bersama Menteri Agama dan Menteri Dalam Negeri tanggal 23 Januari 1978 tentang Peraturan Pelaksanaan Pemerintah Pemerintah Nomor 28 Tahun 1977.

d. Peraturan Direktur Jenderal Bimbingan Masyarakat Islam tanggal 19 April Tahun 1978 No. Kep/Dep/75/1978 tentang Formulir dan Pedoman Pelaksananaan Peraturan- peraturan tentang Perwakafan Tanah Milik.

Atas dasar peraturan di atas, Menteri Agama mengeluarkan Instruksi Nomor 15 Tahun 1989 yang berisi instruksi untuk membentuk tim koordinasi penertiban tanah wakaf di wilayah masing-masing propinsi sampai dengan kabupaten/kotamadya dan kecamatan yang terdiri dari unsur Departemen Agama, Departemen Dalam Negeri, Badan Pertanahan Nasional dan instansi terkait serta Majelis Ulama Indonesia setempat. Tim bertugas mengkoordinasikan, menyelenggarakan dan melaksanakan penertiban tanah wakaf di wilayah masing-masing, dengan upaya menyelesaikan akta ikrar wakaf dan pensertifikatan tanah wakaf berdasarkan Peraturan Pemerintah Nomor 28 Tahun 1977.

Proses perwakafan sangat sederhana dan mudah pelaksanaannya. Namun perwakafan dapat menimbulkan masalah karena tidak dilakukannya proses pencatatan atau pendaftaran guna mendapatkan alat bukti berupa Sertifikat Hak atas Tanah Wakaf. Hal tersebut dapat 
menimbulkan sengketa dikemudian hari ketika Wakif, Nazhir dan saksisaksi telah meninggal dunia. Hal ini juga menyebabkan para pihak yang tidak bertanggungjawab dapat mengingkari keberadaan tanah wakaf tersebut.

Setiap tanah wakaf harus terdaftar pada Badan Pertanahan Nasional guna menjaga keamanan, kelestarian dan tertip administrasi, sebagaimana ditegaskan Pasal 32 Undang-Undang Wakaf bahwa PPAIW atas nama Nazhir mendaftarkan harta benda wakaf ke instansi yang berwenang paling lambat 7 (tujuh) hari kerja sejak akta ikrar wakaf ditandatangani. Nazhir memiliki peran juga dalam menjamin untuk menjaga kepastian hukum terhadap tanah wakaf. Status setiap tanah wakaf harus jelas tentang kepastian hukum mengenai kepemilikannya dan perlindungan hukumnya. Nazhir berkewajiban mengusahakan kelengkapan sertifikat dari tanahwakaf yang dikelolanya sebagai alat bukti kepemilikan yang sah terhadap tanah wakaf.

Jika dilihat data pada Kantor Kementrian Agama Kota Banda
Aceh, harta tanah wakaf diseluruh wilayah Kota Banda Aceh jumlahnya cukup banyak, pada tahun 2015 sudah mencapai 751 Persil/Lokasi yang luasnya mencapai 797.610.61 $\mathrm{M}^{2}$.Dari seluruh tanah wakaf tersebut sebanyak 300 persil/lokasi $(39,95 \%)$ belum bersertifikat, sehingga masih sangat rawan terhadap terjadinya gangguan keamanan kelestarian terhadap harta tanah wakaf dan dapat menimbulkan sengketa terhadap tanah wakaf tersebut.

Hal tersebut di atas terjadi karena sebagian masyarakat belum mengetahui, memahami dan mentaati ketentuan perwakafan yang ada. Ketidaktahuan masyarakat mengenai peraturan perundang-undangan tentang wakaf mungkin disebabkan kurangnya sosialasi khususnya masyarakat pedesaan yang letak wilayahnya jauh dari pusat pemerintahan daerah dan pihak atau instansi yang berkompeten untuk melakukan sosialisasi tersebut. Terhadap tanah wakaf yang belum bersertifikat tentu sangat tidak dikehendaki dan dapat menimbulkan kekawatiran terhadap keutuhan serta keamanannya.

Untuk 
mengantisipasinya maka peran aktif Nazhir sangat diperlukan agar tanah wakaf tetap terjaga dan dikelola sesuai tujuan dan fungsinya.

Pensertifikatan tanah wakaf merupakan keharusan. Tanah wakaf sangat memerlukan suatu perhatian yang sungguh-sungguh agar tanah wakaf jangan sampai beralih penguasaannya kepada pihak ketiga secara melanggar hukum dan jangan sampai harta tanah wakaf itu terbengkalai atau tidak terurus, terlantar.

\section{Peran Nazhir Dalam}

Pengelolaan Wakaf Produktif di

\section{Kota Banda Aceh}

Kegiatan pengelolaan tanah wakap memerlukan suatu perhatian yang sungguh-sungguh guna mewujudkan tujuan dan fungsi wakaf, tanah wakaf harus diberdayakan secara optimal.

Pemberdayaan tanah wakaf hasilnya akan mengarah pada pengembangan pemanfaatan maupun pengembangan modal, sehingga keberadaan tanah wakaf akan tetap utuh bahkan dari hasil usaha produktifitas akan dapat memperbesar harta wakaf itu sendiri. Terhadap tanah wakaf yang dalam realitanya telah diberdayakan secara langsung keberadaan tanah wakaf itu akan selalu terawasi, sehingga tetap terjaga keutuhannya dengan baik, serta keberadaan harta tanah wakaf juga akan selalu terkontrol dengan baik.

Tanah milik yang oleh Wakif telah diikrarkan untuk diwakafkan berarti status kepemilikan telah lepas menjadi harta wakaf, untuk selanjutnya harta tanah wakaf diserahkan kepada Nazhir untuk dikelola sesuai dengan tujuan dan fungsi wakaf. Nazhir merupakan salah satu unsur wakaf yang harus ada dalam praktek pelaksanaan wakaf. Nazhir memiliki tugas dan kewenangan mengelola, mengembangkan juga menjaga keutuhan dan kelestarian harta benda wakaf. Namun yang menjadi masalah adalah bahwa tugas kewenangan untuk mengelola harta tanah wakaf tersebut belum sepenuhnya dapat diwujudkan sebagaimana yang diharapkan masyarakat yaitu pada prinsipnya untuk membantu mewujudkan kesejahteraan umum.

$$
\text { Berhasil atau tidaknya }
$$
mewujudkan tujuan dan fungsi wakaf 
itu sangat tergantung kepada Nazhir. Seorang Nazhir dalam pengelolaan tanah wakaf agar dapat berjalan dengan baik maka diperlukan adanya suatu syarat kwalifikasi tertentu bagi seorang Nazhir, seperti yang berupa penguasaan pengetahuan yang cukup sesuai dengan bidang tugasnya, kemampuan yang dapat diandalkan dan keterampilan yang memadai. Hal tersebut sangat diperlukan guna menunjang tugas yang diembannya.

Dalam rangka mempersiapkan sumber daya manusia sebagai Nazhir yang memadai, maka sebaiknya di dalam perekrutan terhadap Nazhir itu harus dilakukan secara selektif dengan memperhatikan pada aspek keahlian, ketrampilan dan kemampuan professional yang diperlukan. Persyaratan kualitatif inilah sebagai modal dasar bagi Nazhir yang selama ini belum sepenuhnya terpenuhi oleh Nazhir, sehingga dapat menjadi kendala untuk dapat mengelola harta tanah wakaf itu secara efektif dan efisien. Nazhir diberikan suatu tanggungjawab langsung atas pengelolaan kemanfaatan terhadap tanah wakaf sesuai dengan tujuan dan fungsi wakaf yang telah diamanatkan kepadanya, oleh karena itu sebagai Nazhir harus memenunuhi kualifikasi landasan sifat moral sesuai dengan fikih yang antara lain adalah harus beragama Islam dan harus memiliki sifat amanah, jujur, adil.

Guna menjamin keamanan dan kepastian hukum terhadap tanah wakaf maka seorang Nazhir dituntut untuk bekerja secara giat dan professional untuk mengusahakan agar tanah wakaf yang menjadi tanggungjawabnya dapat dilengkapi dengan sertifikat kepemilikannya serta dikelola pemanfaantannya secara efektif dan efisien.

Sehubungan pengelolaan tanah wakaf oleh Nazhir di Kota Banda Aceh yang belum optimal sebagai pemberdayaan ekonomi masyakarat sebagaimana dikehendaki UndangUndang Wakaf, dipengaruhi oleh beberapa faktor, yaitu :

a. Adanya Nazhir yang kurang professional dalam mengelola harta tanah wakaf.

Guna mengelola tanah wakaf hendaknya Nazhir telah memiliki pengetahuan dan ketrampilan yang dapat diandalkan, serta kemampuan menejerial memadai guna menunjang tugasnya, namun syarat tersebut tidak selalu 
terpenuhi. Nazhir wakaf masih kurang professional merupakan salah satu hambatan pengelolaan tanah wakaf. Nazhir dalam melaksanakan pengelolaan tanah wakaf hanya dilakukan dengan kemampuan ketrampilan seadanya dan tidak sesuai kemampuan ketrampilan yang tepat untuk mengelola tanah wakaf, Nazhir tidak memiliki perencanaan pengelolaan yang jelas, dan kemampuan manajerial yang kurang.

b. Adanya sikap bahwa tugas Nazhir hanya sebagai pekerjaan sampingan.

Nazhir yang ditunjuk harusnya siap menjalankan tugas kenazhiran itu sebagai tugas utama, namun kebanyakan Nazhir sudah mempunyai tugas pokok lain yang harus ditunaikan misalnya sebagai Imam Mesjid, Pegawai Negeri, Pegawai Swasta, Pengusaha dan sebagainya. Adapun syarat harus adanya Nazhir dalam proses perwakafan itu hanya sarat formalitas saja. Nazhir kebanyakan dalam melakukan tugasnya hanya sebagai pekerjaan sampingan atau pekerjaan tambahan karena pada umumnya para Nazhir telah memiliki pekerjaan pokok. Nazhir wakaf melakukan tugasnya sekedar untuk memenuhi tugas dan tanggung jawabnya yang telah dipercayakan kepadanya oleh Wakif, Nazhir tidak sepenuhnya untuk menjalankan tugas kenazhiran itu sebagai pekerjaan yang diutamakan.

c. Adanya kebiasaan pengangkatan Nazhir hanya berdasarkan kepercayaan dan kurang mengutamakan segi pengawasaan pengetahuan, kemampuan keterampilan untuk mengelola harta tanah wakaf.

Nazhir yang ditunjuk mengelola tanah wakaf tidak memiliki kemampuan yang memadai untuk mengelola tanah wakaf, Wakif dalam menunjuk Nazhir semata-mata hanya didasarkan kepercayaan saja dan kurang melihat dari segi penguasaan pengetahuan, ketrampilan yang tepat guna membantu tugas-tugas kenazhirannya dalam pengelolaan tanah wakaf. Minimnya kemampuan pengetahuan dan ketrampilan Nazhir hal ini akan menjadi penghambat dalam pengelolaan harta tanah wakaf.

d. Pelaksanaan pelatihan Nazhir yang kurang intensip.

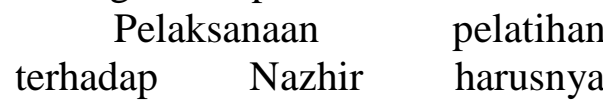
dilakukan secara menyeluruh, namun di dalam prakteknya tidak/belum semua Nazhir mendapatkan kesempatan yang sama untuk diikutkan dalam pelatihan.Pembinaan dan pelatihan yang dilaksanakan oleh pemerintah dalam hal ini Kementrian Agama, atau Baitul Mal belum sepenuhnya dilaksanakan, masih banyak Nazhir yang belum mendapatkan bimbingan dan pelatihan.

$$
\text { Dalam Pasal } 49 \text { ayat }
$$

Undang-Undang Wakaf bahwa Badan Wakaf Indonesia mempunyai tugas dan wewenang melakukan pembinaan terhadap Nazhir dalam mengelola dan mengembangkan harta benda wakaf. 
a. Adanya pemahaman terhadap tujuan dan fungsi wakaf yang masih terbatas.

Pandangan dari wakif ataupun Nazhir yang menganggap bahwa perwakafan semata-mata ditujukan untuk kepentingan sarana ibadah seperti masjid, mushola, sebagai tempat pendidikan, sebagai tempat pemakaman dan sebagainya, dan belum adanya pemahaman yang lebih luas bahwa tanah wakaf dapat dikelola guna kepentingan peningkatan kesejahteraan ekonomi masyarakat.

b. Pengawasan yang kurang teratur/intensif

Pemerintah dan masyarakat harus lebih aktif melakukan pengawasan kinerja Nazhir, mengevaluasi kinerja Nazhir, namun kewajiban tersebut kurang sepenuhnya dijalankan, sehinggga pengawasan kinerja Nazhir berjalan kurang intensif. Pengelolaan dan pemberdayaan sepenuhnya dipercayakan kepada Nazhir dan tidak adanya pengawasan intensif terhadap usaha pengelolaan oleh Nazhir.

c. Nazhir yang tidak melakukan pelaporan terhadap hasil pengelolaannya.

Nazhir memiliki kewajiban melaporkan pengelolaan tanah wakaf setiap tahun, namun tugas pelaporan itu tidak dilakukan Nazhir. Tindakan Nazhir yang tidak melaporkan hasil usaha pengelolaan harta wakaf yang ditugaskan kepadanya akan menghambat bagi Badan Wakaf Indonesia dan Pemerintah menjalankan tugasnya sebagai pengawas.

\section{Upaya Pemberdayaan Tanah Wakaf Produktif di Kota Banda Aceh}

Pada zaman dahulu, orangorang kaya di Banda Aceh berlombalomba memberikan sebahagian hartanya dengan jalan mewakafkannya, misalnya sawah, kebun, membangunkan suatu rumah ibadah, dengan mengharapkan pahala dari pada Allah. Pada kebiasaannya, harta wakaf diserahkan kepada ketua kampung dan Imam meunasah. Kemudian mereka ini menyampaikan laporan kepada Uleebalang yang bersangkutan untuk didaftarkan.

\section{Menurut Adat, Ketua kampung} mendapatkan satu bahagian dari pada hasil wakaf untuk penghidupannya. Dengan demikian petugas negeri dapat hidup dan tidak perlu merampas harta rakyatnya. Rakyat turut mengawasi agar harta Allah itu (areuta wakeueh) tidak dijual Nazhirnya atau disalahgunakan. Hal ini pun telah menjadi suatu adat di Aceh pada zaman dahulu (Moehammad Hoesin, 1970:144).

Dengan latar belakang Banda Aceh sebagai wilayah yang mayoritas 
penduduknya adalah muslim serta pernah wujud kerajaan Aceh Darussalam pada masa dahulu, maka sudah pasti di Kota Banda Aceh banyak terdapat tanah wakaf dari masa ke semasa yang memiliki peranan yang signifikan dalam mensejahterakan masyarakatnya bila dikembangkan secara profesional.

Berdasarkan data pada Kantor Wilayah Kementrian Agama Kota Banda Aceh pada tahun 2015, tanah wakaf di 9 Kecamatan di Kota Banda Aceh berjumlah 751 lokasi dengan luas 797.610.61 $\mathrm{m}^{2}$. Dari Jumlah tersebut, yang sudah bersetifikat 450 lokasi dengan luas $508.161 .08 \mathrm{~m}^{2}$, dan yang belum mempunyai sertifikat 290 lokasi dengan luas 266.249.53 $\mathrm{m}^{2}$. Ini menunjukkan bahwa 60 persen daripada tanah wakaf di Kota Banda Aceh telah memiliki sertifikat tanah wakaf dari Badan Pertanahan Nasional.

Dari pada jumlah tanah wakaf di Kota Banda Aceh yang begitu besar, hanya sebahagian kecil dimanfaatkan secara produktif dan memberikan kesejahteraan kepada masyarakat. Pemanfaatan tanah wakaf oleh Nazhir masih bersifat konsumtif dan konvensional. Sangat sedikit jumlah Nazhir yang melakukan pembangunan tanah wakaf secara profesional.

Perkembangan wakaf di Aceh masih dalam tahapan pendaftaran tanah wakaf, belum sampai kepada tahapan pembangunan secara profesional. Untuk memudahkan proses pensertifikatan, Kementerian Agama Propinsi Aceh mendapatkan bantuan keuangan Kementerian Agama Pusat, Badan Wakaf Indonesia, dan dana anggaran dari Kementerian Agama Propinsi Aceh, yaitu :

a. Tahun 2012 sebanyak 150 lokasi, satu lokasi satu juta rupiah. Dibagikan kepada $11 \mathrm{kab} /$ kota.

b. Tahun 2013 sebanyak 200 lokasi, satu lokasi satu juta rupiah. Dibagikan kepada 7 Kab/ Kota.

c. Tahun 2014 sebanyak 230 lokasi dengan total bantuan 365 juta rupiah dalam bentuk proposal.

d. Tahun 2015 melalui DIPA (Daftar Isian Pelaksanaan Anggaran) pejabat wilayah Kementerian Agama Aceh sebanyak 650 lokasi, satu lokasi 2 juta rupiah, total 1,3 M.

Total bantuan selama empat tahun adalah Rp 2.215,000.000, sebanyak 1,430 lokasi telah pun mempunyai sertifikat tanah wakaf 
secara rasmi. Bantuan pensertifikatan ini diserahkan kepada forum Nazhir yang telah wujud di setiap wilayah di Aceh. Jumlah bantuan dana yang diterima setiap wilayah berbeda bergantung proposal yang diajukan kepada Kementerian Agama. Dengan adanya bantuan dana untuk pensertifikatan ini ini maka jumlah tanah wakaf yang akan mempunyai sertifikat sampai tahun 2015 adalah 14,380 lokasi, sedangkan yang belum bersertifikat pun akan berkurang menjadi 10.518 lokasi. Kalau seandainya pengurusan sertifikat tanah wakaf Rp 2.000,000 untuk setiap lokasi berdasarkan bantuan pensertifikatan tahun 2015, maka diperlukan Rp 21.036,000,000 untuk pensertifikatan tanah wakaf pada tahun 2015 yang berjumlah 10.518 lokasi. Untuk tahun-tahun ke depan, setiap pewakif diharapkan untuk memberikan sejumlah wang kepada nazhir untuk menguruskan pensertifikatan tanah wakaf, sehingga tanah wakaf tidak akan dipersengketakan di masa yang akan datang kerana telah memiliki sertifikatan sebagai tanah wakaf dari Badan Pertanahan Nasional.
Dampak dari tidak adanya sertifikat tanah wakaf di Aceh adalah berlakunya permasalahan, persengketaan dan perebutan tanah wakaf dalam masyarakat selama ini sehingga tanah wakaf akan terjaga selamanya.Di kampung-kampung di Kota Banda Aceh ini, tanah wakaf diserahkan oleh pewakaf kepada Nazhir dengan mengikrarkan dihadapan saksi disertai penyerahan sertifikat tanah tersebut, sehingga tanah tersebut tidak memiliki sertifikat sebagai tanah wakaf dari Badan Pertanahan Nasional, kerana bagi masyarakat yang hendak mewakafkan hartanya tidak dibebankan untuk menguruskan sertifikat tanah wakaf, hanya ikrar dan penyerahan sertifikat hak milik tanah kepada Imam Masjid atau Keuchik di hadapan saksi.

Pembangunan tanah wakaf di daerah ini belum dikelola dengan baik oleh Nazhir disebabkan kurangnya pemahaman Nazhir terhadap wakaf, lokasi tanah wakaf yang tidak strategis, kurangnya sosialisasi dan kurangnya permodalan dan kemampuan masyarakat dalam pembangunan tanah wakaf. 
Tanah wakaf di Banda Aceh banyak yang terbengkalai dan tidak diberdayakan. Sedangkan tanah yang diberdayakan masih menggunakan cara-cara tradisional sehingga hasil daripada tanah wakaf itu tidak mampu memberikan kesejahteraan kepada Nazhir itu sendiri dan juga kepada masyarakat pada umumnya. Hambatan yang didapati hampir sama dengan di daerah lainnya di Aceh, di antaranya adalah kurangnya kemampuan Nazhir, kurangnya permodalan dalam pembangunan tanah wakaf dan letak tanah wakaf yang tidak strategis.

Usaha ke arah pemberdayaan aset wakaf telah pun dilakukan oleh berbagai pihak yang ada di Banda Aceh. Pemerintah telah membentuk institusi pengelola harta wakaf iaitu Baitul Mal Aceh dan Kementerian Agama Provinsi Aceh. Keduadua institusi ini telah pun melakukan berbagai usaha mengembangkan wakaf. Adapun usaha-usaha yang telah dan sedang dilakukan adalah usaha pensertifikatan kepada setiap harta wakaf yang ada di Aceh kerana terdapat banyak lagi aset wakaf yang tidak mempunyai sertifikat, sehingga banyak berlaku pertikaian oleh pihakpihak tertentu terhadap harta wakaf.

Selain daripada pensertifikat, institusi wakaf di Aceh melakukan training dan pelatihan kepada Nazhir dalam upaya meningkatkan kemampuan mereka dalam mengelola aset wakaf di Aceh sehingga wakaf akan memberikan dampak yang lebih besar kepada kesejahteraan masyarakat Aceh khususnya Kota Banda Aceh.

Dengan demikian, wakaf harus dikembangan secara optimal, dengan pengelolaan profesional, produktif, untuk mencapai hasil yang nyata dalam kehidupan bermasyarakat. Langkah awal dalam melaksanakan wakaf produktif ini adalah dengan menghilangkan segala kendala yang dihadapi selama ini dalam mengelola wakaf, terutama tidak produktifnya harta benda wakaf. Nazhir yang kurang profesional dan administrasi pengelolaan wakaf yang tidak tertib. Semua harta wakaf yang mempunyai nilai komersial yang tinggi ditata kembali dan hasilnya untuk kesejahteraan masyarakat.

\section{SIMPULAN}


Wakaf merupakan salah satu sumber pemberdayaan ekonomi umat. Bahwa lembaga wakaf sebagai pranata keagamaan memiliki potensi dan manfaat ekonomi perlu dikelola secara efektif dan efesien untuk kepentingan ibadah dan memajukan kesejahteraan umum. Implementasi Undang-undang Nomor 41 Tahun 2004 tentang Wakaf untuk peningkatan kesejahteraan masyarakat di Kota Banda Aceh melalui wakaf tanah produktif belum memberikan kontribusi terhadap peningkatan kesejahteraan masyarakat, disebabkan paham umat Islam tentang wakaf, banyaknya tanah wakaf yang tidak strategis dan pro kontra mengenai pengalihan wakaf untuk tujuan produktif, banyaknya tanah wakaf yang belum bersertifikat, nazhir masih tradisional dan konsumtif. Konsep pemberdayaan adalah membangun daya masyarakat dengan mendorong, memotivasi dan membangkitkan kesadaran akan potensi yang dimiliki serta berupaya mengembangkannya. Pemberdayaan tanah wakaf dalam pemberdayaan ekonomi umat sebagai peningkatan

kesejahteraaan masyarakat melalui tanah wakaf produktif, peningkatan kompetensi nazhir dalam pengelolaan wakaf tanah produktif, serta menjadikan Nazhir sebagai sebuah profesi yang menuntut profesionalisme, dan memungkinkan dimasa yang akan datang tanah kuburan dapat diproduktifkan.

\section{SARAN}

1. Perlu meningkatkan peran wakaf sebagai pranata keagamaan yang tidak hanya bertujuan menyediakan berbagai sarana ibadah dan sosial, tetapi juga memiliki kekuatan ekonomi yang berpotensi, antara lain memajukan kesejahteraan umum, sehingga perlu dikembangkan pemanfaatannya sesuai dengan prinsip syariah, di samping juga perlu adanya manajemen Nazhir yang profesional dan amanah dalam pengelolaan tanah wakaf sebagai salah satu upaya pemberdayaan ekonomi umat, serta perlu adanya suatu pengawasan secara 
berkesinambungan oleh instansi terkait terhadap pelaksanaan perwakafan yang ada di dalam masyarakat sehingga penyimpangan-penyimpangan yang terjadi dapat dihindari.

2. Hendaknya pemerintah memprogramkan serta melakansakan pilot project mengenai wakaf produktif di Kota Banda Aceh dengan menyediakan anggaran yang bersumber dari APBN dan APBD dalam rangka pemberdayaan wakaf produktif. Untuk mendukung pengembangan wakaf tanah produktif, maka : Menjadikan Nazhir sebagai profesi yang menuntut professionalisme yang diimbangi dengan imbalan yang menjadikannya mampu bekerja sesuai tuntutan profesionalitas kerja, dan Proses pemberdayaan ini ditingkatkan usaha produktif dengan menjalin kerjasama dengan badan usaha yang telah memiliki reputasi, atau membangun kemitraan.

\section{DAFTAR PUSTAKA}

Abdurrahman, Masalah Perwakafan Tanah Milik dan Kedudukan Tanah Wakaf di Negara Kita, Citra Aditya Bakti, Bandung, 1994.

Achmad Djunaidi dan Thobieb alAsyhar, Menuju Era Wakaf Produktif, Mitra Abadi Press, Jakarta, 2005.

Adijani al Alabij, Perwakafan Tanah di Indonesia Dalam Teori dan Praktek, Rajawali Pers, Jakarta, 1989.

Ahmad Azhar, Refleksi Atas Persoalan Keislaman, Mizan, Bandung, 1993.

Andi Tahir Hamid, Beberapa Hal Baru Tentang Peradilan Agama dan Bidangnya, Sinar Grafika, Jakarta, 2005.

Departemen Agama Republik Indonesia, Perkembangan Pengelolaan Wakaf di Indonesia, Proyek Peningkatan Zakat danWakaf Direktorat Jenderal Bimbingan Masyarakat Islam dan Penyelenggaraan Haji, Jakarta, 2003.

Harun Nasution, Ensiklopedia Islam Indonesia, Djambatan, Jakarta, 1998.

Hasbi A R, Wakaf, IAIN Sumatera Utara, Medan, 1985.

Ismail Muhammad Syah, Filsafat Hukum Islam, Bumi Aksara, Jakarta, 1994. 
M. Hasballah Thaib, Tajdit, Reaktualisasi dan Elastisiitas Hukum Islam, Konsentrasi Hukum Islam Program Pasca Sarjana Ilmu Hukum Universitas Sumatera Utara Medan, 2002.

Moehammad Hoesin, Adat Atjeh, Dinas Pendidikan dan Kebudajaan Propinsi Daerah Istimewa Atjeh, Banda Aceh, 1970.

Mohammad Koesno, Wakaf Tanah Dalam Sistem Hukum Nasional Kita,Makalah Seminar Wakaf Tanah Dalam Sistem Hukum Nasional, Fakultas Hukum Universitas Islam Riau, Pekanbaru, 1991.

M. Thaher Azhary, Wakaf dan Sumber Daya Ekonomi, Suatu Pendekatan Teoritis, Mimbar Hukum Nomor 7 Tahun III, AlHikmah dan Direktorat Pembinaan Badan Peradilan Agama Islam, Jakarta, 1992.

Juhaya S. Praja dan Mukhlisin Muzarie, Pranata Ekonomi
Islam Wakaf, STAIC Press, Cirebon, 2009.

Rachmat Djatniko, Wakaf dan Masyarakat serta Aplikasinya Aspek-aspek Fundamental, Mimbar Hukum, al-Hikmah dan Direktorat Pembinaan Badan Peradilan Agama Islam, Jakarta, 1992.

R. Van Dijk, Pengantar Hukum Adat di Indonesia, (diterjemahan oleh A. Soekardi), Vorkrink van Hove, Bandung, tanpa tahun.

Suparman Usman, Hukum Perwakafan di Indonesia, Darul Ulum Prees, Jakarta, 1999.

Surahwardi K. Lubis, Pembaharuan Hukum Wakaf di Indonesia, Dalam Hukum Islam Dua Negara, Indonesia dan Malaysia, Pengadilan Tinggi Agama Medan, 2012.

Taufik Hamami, Perwakafan Tanah (Dalam Politik Hukum Agraria Nasional), Tata Nusa, Jakarta, 2003. 